\title{
Pengaruh Pemberian Dosis Mineral Ca dan Lama Fermentasi Pelepah Sawit terhadap Kandungan Lignin, Kecernaan BK, BO, PK dan Fraksi Serat (NDF, ADF, Hemiselulosa dan Selulosa) menggunakan Kapang Phanerochaete chrysosporium
}

\section{In-vitro digestibility of Nutrients Components of Palm Frond fermented by Phanerochaete chrysosporium supplemented with Calcium}

\author{
S. Rahayu ${ }^{1}$, N. Jamarun ${ }^{2}$, M. Zain ${ }^{2}$ dan D. Febrina ${ }^{3}$ \\ ${ }^{1}$ Fakultas Pertanian dan Peternakan, Universitas Jabal Gafur, Sigli, Aceh \\ ${ }^{2}$ Fakultas Peternakan, Universitas Andalas, Padang \\ ${ }^{3}$ Fakultas Pertanian dan Peternakan, Universitas Islam Negri Sultan Syarif Kasim, Pekanbaru \\ email: novirman55@gmail.com \\ (Diterima: 22 Desember 2014; Disetujui: 10 Maret 2015)
}

\begin{abstract}
ABSTRAK
Pelepah sawit dapat dimanfaatkan sebagai pakan ternak tetapi terkendala karena tingginya kandungan lignin. Strategi yang dapat dilakukan untuk menurunkan kandungan lignin pelepah sawit adalah melalui fermentasi menggunakan kapang Phanerochaete chrysosporium (Pc). Pertumbuhan kapang Phanerochaete chrysosporium dipengaruhi oleh ketersediaan mineral dalam substrat. Untuk itu diperlukan penambahan mineral sesuai dengan kebutuhan kapang dimana salah satunya adalah mineral kalsium $(\mathrm{Ca})$. Penelitian ini bertujuan untuk melihat pengaruh pemberian dosis mineral $\mathrm{Ca}$ dan lama fermentasi dalam menurunkan kandungan lignin, meningkatkan kecernaan BK, BO, PK, NDF, ADF, Selulosa dan Hemiselulosa pelepah sawit yang difermentasi menggunakan kapang Phanerochaete chrysosporium. Penelitian ini menggunakan Rancangan Acak Lengkap (RAL) pola faktorial untuk menghitung persentase penurunan lignin dan Rancangan Acak Kelompok (RAK) pola faktorial dengan tiga kali ulangan. Faktor A yaitu pemberian dosis mineral Ca yaitu A0: kontrol (pelepah $+\mathrm{Pc})+0$ ppm Ca, A1: kontrol + 1000 ppm Ca, A2 : kontrol +1500 ppm Ca, A3 : kontrol + 2000 ppm Ca. Faktor B adalah lama waktu fermentasi yaitu Y1: 10 hari, Y2 : 15 hari dan Y3 : 20 hari. Data dianalisis menggunakan analisa varian (Anova) dan untuk melihat perbedaan antar perlakuan dilakukan uji lanjut Duncan's Multiple Range Test (DMRT) (Steel and Torrie, 1991). Hasil sidik ragam menunjukkan perlakuan memberikan pengaruh berbeda nyata $(\mathrm{P}<00.1)$ terhadap penurunan kandungan lignin, kecernaan $\mathrm{BK}, \mathrm{BO}, \mathrm{PK}, \mathrm{NDF}, \mathrm{ADF}$, Hemiselulosa dan Selulosa. Penelitian ini dapat disimpulkan bahwa fermentasi pelepah sawit menggunakan kapang Phanerochaete chrysosporium pada dosis mineral Ca 2000 ppm dengan lama fermentasi 10 hari dapat menurunkan kandungan lignin $26,79 \%$ dengan kecernaan BK 51,44\%., BO 53,24\%., PK 47,54\%., NDF 47,48\%., ADF 42,24\%., Selulosa 45,44\% dan Hemiselulosa 48,34\%.
\end{abstract}

Kata kunci: kapang Phanerochaete chrysosporium, mineral Ca, pelepah sawit

\section{ABSTRACT}

Oil Palm Frond as agricultural residue can be used as animal feed, but due to high lignin content the used are very limited. Strategy to reduce its lignin can be done through fermentation using fungi of Phanerochaeta chrysosporium as biodelignificatian agent. The growth of fungi depent on availability of some minerals especially calcium $(\mathrm{Ca})$ in the substrate. The aim of this experiment was to determine the effect of Calcium supplementation on digestibility of Dry matter, Organic matter, Crude Protein, Neutral Detergent Fiber (NDF), Acid Detergent Fiber (ADF), Sellulose and Hemicellulose. The experiment used Completely Randomized design in factorial to determine the decrease of lignin content in three replications. Factor A was Ca supplementation: 
AO : control (Oil Palm Frond + O ppm Ca), A1 : control + 1.000 ppm Ca, A2 : control + 1.500 ppm $\mathrm{Ca}$, and $\mathrm{A} 3$ : control $+2.000 \mathrm{Ca}$. Factor $B$ was fermentation time that were : Y1 : 10 days, Y2 $: 15$ days, and $Y 3: 20$ days. Data were analyzed using Analysis of Variance and to determine the differences among treatment means used Duncan's Multipple Range Test. The results of the experiment indicated that supplementation of $\mathrm{Ca}$ on biodelignification of oil palm frond had decreased lignin content as much as $26.79 \%$ and significantly difference $(P<0.01)$ on decreasing lignin content and digestibility of dry matter, organic matter, Crude protein, Neutral detergent fiber $(N D F)$, acid detergent fiber $(A D F)$, cellulose and hemicellulose. It concluded that utilization of Phanerochaete chrysosporium as biodelignifier on oil palm frond can be used at level of addition of 2.000 ppm Ca with fermentation period of 10 days.

Keywords: Calcium, delignification, digestibility, Oil Palm frond, Phanerochaete chrysosporium

\section{PENDAHULUAN}

Pelepah sawit merupakan salah satu limbah perkebunan kelapa sawit sangat potensial dimanfaatkan sebagai pakan alternatif pengganti rumput. Limbah yang dihasilkan dari perkebunan sawit produksinya melimpah, tidak bersaing dengan kebutuhan manusia, serta pemanfaatannya yang belum optimal.

Luas perkebunan sawit pada tahun 2012 adalah 9.572.715 Ha, tahun 2013 adalah 10.010.824 $\mathrm{Ha}$ atau mengalami peningkatan sebesar $4.58 \%$ (Direktorat Jenderal Perkebunan Indonesia, 2012). Ditjen PPHP (2006) menyebutkan satu hektar luas kebun kelapa sawit terdiri dari 130 batang sawit. Setiap batang kelapa sawit dapat dipanen 22 buah pelepah/tahun. Setiap pelepah berat rata-rata 7 $\mathrm{kg}$ dan setiap ekor sapi membutuhkan lebih kurang empat pelepah/hari, dari satu pelepah kelapa sawit dapat dihasilkan 3,333 $\mathrm{kg}$ daun kelapa sawit (Ishida dan Hassan, 1992). Hasil analisa laboratorium menunjukkan kandungan gizi pelepah sawit adalah BK 46,2 \%., BO 87,95\%., PK 5,75\%., NDF 73,25\%., ADF $54,62 \%$., hemiselulosa 18,63\%., selulosa 25,75\%., lignin 28,87\%., kecernaan BK $35,37 \%$ dan kecernaan BO 36,54\% (Labor Nutrisi Ruminansia Fakultas Peternakan Universitas Jambi, 2014). Pemanfaatan pelepah sawit sebagai pakan sangat terbatas karena tingginya kandungan lignin yang menyebabkan kecernaan pelepah sawit menjadi rendah. Kandungan protein kasar daun sawit 5,75\% lebih rendah dibandingkan dengan protein kasar rumput 10,07-13,87\%
(Alimon dan Hair-Bejo, 1996; Sirait, dkk. 2005).

Untuk meningkatkan penggunaan pelepah sawit dalam ransum diperlukan usaha untuk menurunkan kandungan lignin dan salah satunya melalui teknik fermentasi menggunakan mikroorganisme yang memiliki kemampuan mendegradasi lignin. Ligninase adalah enzim pendegradasi lignin yang dihasilkan mikroorganisme yang bersifat lignophilik. Ikatan lignoselulosa dapat diputus oleh ligninase seperti lignin peroksidase (LiP), mangan peroksidase $(\mathrm{MnP})$ dan laccase (Takano, et al. 2004). Enzim LiP dan MnP dihasilkan oleh beberapa mikroorganisme termasuk kapang Phanerochaete chrysosporium (Zacchi, et al. 2000). Phanerochaete chrysosporium adalah kapang dari kelas Basidiomycetes yang mempunyai kemampuan kuat merombak lignin secara efektif (Leisola dan Garcia, 1989). Penggunaan kapang Phanerochaete chrysosporium pada biodelignifikasi pelepah sawit diharapkan dapat memutus ikatan selulosa dan hemiselulosa dari lignin sehingga dapat meningkatkan kualitas pelepah sawit. Fadilah dan Distantina (2009) menyatakan pada proses penghancuran lignin (delignifikasi) secara biologis faktor yang perlu diperhatikan adalah spesies jamur yang digunakan, ukuran dan bentuk inokulum, jenis bahan yang diolah, perlakuan awal bahan, waktu inkubasi, aerasi, dan nutrisi.

Pertumbuhan kapang Phanerochaete chrysosporium dipengaruhi oleh ketersediaan mineral dalam substrat, untuk itu diperlukan penambahan mineral sesuai dengan kebutuhan 
kapang seperti mineral Ca dan Mn. Wuyep et al. (2003) menyatakan ion Ca dapat memacu pertumbuhan dan perpanjangan miselia. Penambahan mineral Ca 2400-3200 ppm mampu menghasilkan pertumbuhan dan aktivitas enzim ligninolitik terbaik pada $L$. squarrosulus dan $P$. atroumbonata. Hasil penelitian Nelson (2011) menyebutkan kapang mencapai pertumbuhan maksimal pada penambahan Ca 1190 ppm.

Fermentasi menggunakan kapang Phanerochaete chrysosporium merupakan langkah strategis dalam memperbaiki kualitas pelepah sawit dan meningkatkan kecernaan. Penambahan mineral $\mathrm{Ca}$ pada penelitian ini juga dilihat pengaruh waktu inkubasi dalam proses delignifikasi. Nelson dan Suparjo (2011) menyatakan fermentasi kulit buah kakao dengan penambahan $1190 \mathrm{ppm} \mathrm{Ca}$ selama 10 hari memberikan hasil terbaik yaitu degradasi lignin $(38,61 \%)$, efisiensi biodegradasi lignin $(5,65 \%)$.

Penelitian ini bertujuan untuk mengevaluasi pengaruh pelepah sawit yang difermentasi menggunakan kapang Phanerochaete chrysosporium ditambah mineral $\mathrm{Ca}$ dan lama fermentasi terhadap persentase kandungan lignin, kecernaan $\mathrm{BK}, \mathrm{BO}, \mathrm{PK}$, NDF, ADF, hemiselulosa dan selulosa. Penelitian diharapkan dapat menyumbangkan informasi dalam upaya menambah keanekaragaman bahan pakan ternak ruminansia dengan memanfaatkan limbah perkebunan kelapa sawit terutama limbah lapangan yaitu pelepah sawit.

\section{METODE}

\section{Tempat Penelitian}

Penelitian dilaksanakan di Laboratorium Patologi, Entomologi dan Mikrobiologi Fakultas Pertanian dan Peternakan Universitas Islam Negeri Sultan Syarif Kasim Riau dan Laboratorium Nutrisi Ruminansia Fakultas Peternakan Universitas Jambi.

\section{Bahan dan Alat}

Bahan yang digunakan dalam penelitian adalah pelepah sawit, kapang Phanerochaete chrysosporium, sumber mineral $\mathrm{Ca}$ yaitu
$\mathrm{CaCl} 2$, larutan $\mathrm{Mc}$ Dougall, medium Potato Dextrose Agar (PDA) dan cairan rumen yang berasal dari Sapi Fistula. Peralatan yang digunakan dalam penelitian adalah seperangkat alat-alat untuk in vitro, seperangkat alat-alat untuk fermentasi, dan seperangkat alat-alat untuk analisa Proksimat, Van Soest, autoclave dan timbangan analitik.

\section{Rancangan Penelitian}

Untuk menghitung persentase penurunan kandungan lignin menggunakan Rancangan Acak Lengkap pola faktorial (4 $\mathrm{x}$ 3 ) dengan 3 kali ulangan. Untuk menghitung kecernaan dan karakteristik cairan rumen menggunakan Rancangan Acak Kelompok pola Faktorial (4 x 3) dengan 3 kali ulangan.

Faktor A adalah pemberian mineral, yaitu:

A0 $=$ Pelepah sawit $+P$. chrysosporium tanpa penambahan mineral.

$\mathrm{A} 1=$ Pelepah sawit $+P$. chrysosporium + mineral Ca $1.000 \mathrm{ppm}$.

$\mathrm{A} 2=$ Pelepah sawit $+P$. chrysosporium + mineral Ca 1.500 ppm.

$\mathrm{A} 3=$ Pelepah sawit $+P$. chrysosporium + mineral Ca $2.000 \mathrm{ppm}$.

Faktor B adalah lama waktu fermentasi yaitu:

$\mathrm{Y} 1=10$ hari

$\mathrm{Y} 2=15$ hari

$\mathrm{Y} 3=20$ hari

Penggunaan dosis inokulum adalah $10 \%$ dari bahan kering (BK) sampel (Nelson, 2011). Data yang diperoleh dianalisis menggunakan analisa varian (Anova) dan untuk melihat perbedaan antar perlakuan dilakukan pengujian dengan menggunakan uji lanjut Duncan's Multiple Range Test (DMRT) (Steel and Torrie, 1991).

\section{Pelaksanaan Penelitian}

1. Pelepah sawit dicincang hingga berukuran $1.5-2 \mathrm{~cm}$ kemudian dijemur, digiling dan siap dianalisis untuk analisis awal sampel, meliputi kandungan $\mathrm{BK}, \mathrm{BO}, \mathrm{PK}, \mathrm{ADF}$, $\mathrm{NDF}$, hemiselulosa, selulosa dan lignin.

2. Peremajaan kapang Phanerochaete chrysosporium dilakukan selama 7 hari pada medium Potato Dextrose Agar (PDA). 
3. Larutan Mc Dougall berfungsi sebagai buffer dalam fermentasi in vitro. Larutan buffer dipersiapkan sehari sebelum in vitro dan diletakkan dalam shaker waterbath dengan suhu $39^{\circ} \mathrm{C}$ dan gas $\mathrm{CO}_{2}$ dialirkan selama 60 detik sehingga kondisi tetap anaerob dan pHnya diatur mendekati 7 dengan menggunakan $\mathrm{NaOH} 20 \%$ atau $\mathrm{H}_{3} \mathrm{PO}_{4} 20 \%$.

4. Pengukuran kecernaan secara in vitro berdasarkan modifikasi prinsip Tilley and Terry (1963).

\section{Parameter yang diukur}

1) Penurunan Lignin

Penurunan kandungan lignin dalam substrat sebelum dan setelah fermentasi dihitung dengan persamaan:

Penurunan lignin $(\%)=\frac{\text { Lo-Lt }}{\text { Lo }} \times 100 \%$

Keterangan:

Lo: Kandungan lignin substrat sebelum fermentasi (\%)

Lt: Kandungan lignin substrat setelah fermentasi (\%)

2) Kecernaan Bahan Kering (\%)

$\mathrm{KcBk}=\frac{(\text { E.Sampel } \mathrm{BK})-(\text { B.Kesidux BK }- \text { Bi, Blanhox BK })}{\text { B.sampel } \mathrm{xBK}} \mathrm{x} 100 \%$

3) Kecernaan Bahan Organik (\%)

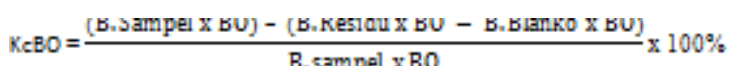

4) Kecernaan Protein Kasar

$\mathrm{K} c \mathrm{PK}=\frac{(\text { B.awalx BKxPK })-(\text { B.ResiduxBKx PK) }}{\text { B.awalx BKx PK }} 1008 \%$
5) Kecernaan NDF

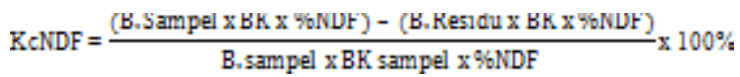

6) Kecernaan $\mathrm{ADF}$

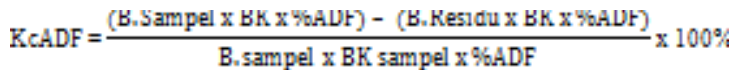

7) Kecernaan Selulosa

$\mathrm{K} C \mathrm{SI}=\frac{(\mathrm{B}, \text { Sampelx BKx 9651) - (B., Residux BKx 9651) }}{\text { B. sampelx BK sampelx 9ESI }} \mathrm{x}$ 100\%

Keterangan:

$\mathrm{Sl}=$ Selulosa

8) Kecernaan Hemiselulosa

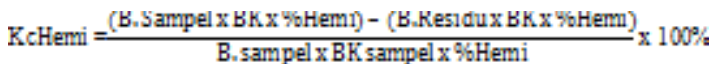

Keterangan:

Hemi $=$ Hemiselulosa

\section{HASIL DAN PEMBAHASAN}

a. Penurunan Kadar Lignin

Rataan penurunan kandungan lignin pelepah sawit yang difermentasi kapang Phanerochaete chrysosporium pada masingmasing perlakuan dilihat pada Tabel 1.

Hasil sidik ragam menunjukkan terdapat interaksi $(\mathrm{P}<0,01)$ antara pemberian dosis mineral (A) dengan lama fermentasi (Y) terhadap peningkatan penurunan kandungan lignin pelepah sawit yang difermentasi kapang Phanerochaete chrysosporium. Besarnya persentase penurunan kandungan lignin pada perlakuan A3Y1 (pemberian dosis 2.000 ppm dengan lama 10 hari) menunjukan telah terjadi penurunan kandungan lignin pelepah sawit dari $28,87 \%$ menjadi $21,23 \%$ (penurunan

Tabel 1. Rataan penurunan kandungan lignin (\%).

\begin{tabular}{|c|c|c|c|c|c|}
\hline \multirow{2}{*}{ Waktu (Y) } & \multicolumn{4}{|c|}{ Dosis } & \multirow[b]{2}{*}{ Rataan } \\
\hline & A0 & A1 & $\mathrm{A} 2$ & A3 & \\
\hline Y1 & $12,85^{\mathrm{g}}$ & $15,95^{\mathrm{e}}$ & $23,47^{\mathrm{c}}$ & $26,79^{\mathrm{a}}$ & 23,71 \\
\hline Y2 & $10,84^{\mathrm{h}}$ & $13,72^{f}$ & $21,27^{\mathrm{d}}$ & $24,73^{\mathrm{b}}$ & 21,74 \\
\hline $\mathrm{Y} 3$ & $7,74^{\mathrm{i}}$ & $11,41^{\mathrm{h}}$ & $20,64^{\mathrm{d}}$ & $21,16^{\mathrm{d}}$ & 19,42 \\
\hline Rataan & 18,77 & 21,69 & 21,79 & 24,23 & 21,62 \\
\hline
\end{tabular}

Keterangan: Superskrip yang berbeda pada baris dan kolom yang sama menunjukkan berbeda sangat nyata $(\mathrm{P}<0,01)$. 
Tabel 2. Rataan kecernaan bahan kering (KcBK) dalam \%.

\begin{tabular}{|c|c|c|c|c|c|}
\hline \multirow{2}{*}{ Waktu (Y) } & \multicolumn{4}{|c|}{ Dosis } & \multirow{2}{*}{ Rataan } \\
\hline & A0 & A1 & A2 & A3 & \\
\hline Y1 & $42,05^{\mathrm{fg}}$ & $45,14^{\mathrm{e}}$ & $47,69^{\mathrm{c}}$ & $51,44^{\mathrm{a}}$ & 46,58 \\
\hline Y2 & $41,28^{\mathrm{gh}}$ & $42,81^{\mathrm{f}}$ & $46,32^{\mathrm{d}}$ & $49,53^{b}$ & 44,99 \\
\hline Y3 & $40,56^{\mathrm{h}}$ & $41,90^{\mathrm{fg}}$ & $44,21^{\mathrm{e}}$ & $47,85^{\mathrm{c}}$ & 43,63 \\
\hline Rataan & 41,30 & 43,28 & 46,07 & 49,60 & 45,06 \\
\hline
\end{tabular}

Keterangan: Superskrip yang berbeda pada baris dan kolom yang sama menunjukkan berbeda sangat nyata $(\mathrm{P}<0,01)$.

$26,79 \%)$. Penurunan kandungan lignin pada A3Y1 (pemberian dosis $2.000 \mathrm{ppm}$ dengan lama 10 hari) disebabkan karena semakin tinggi pemberian mineral $\mathrm{Ca}$ hingga dosis 2000 ppm dengan waktu 10 hari dapat meningkatkan pertumbuhan miselium kapang sehingga enzim yang dihasilkan lebih banyak dan proses degradasi lignin terjadi secara optimal. Hal ini dapat dibuktikan dengan kandungan lignin A3Y1 (2.000 ppm dan 10 hari) setelah fermentasi lebih rendah jika dibandingkan dengan pemberian perlakuan lainnya. Gupte et al. (2007) menyatakan kapang Phanerochaete chrysosporium mampu menurunkan kandungan lignin 20,5\% pada hari ke-10 inkubasi dan menunjukkan aktivitas enzim yang maksimum dalam mendegradasi lignin. Suparjo (2010) menyatakan penambahan $\mathrm{Ca}$ secara individual mampu meningkatkan enzim lignin peroksidase (LiP). Fadilah et al. (2009) menyatakan penambahan nutrisi akan meningkatkan laju degradasi lignin serta meningkatkan pertumbuhan jamur.

Rendahnya penurunan lignin pada perlakuan pemberian dosis $1.000 \mathrm{ppm}, 1.500$ ppm disebabkan karena pemberian dosis tersebut belum dapat mengoptimalkan pertumbuhan miselia kapang sehingga enzim yang dihasilkan sedikit dan membuat kerja enzim yang dihasilkan oleh kapang dalam mendegradasi lignin belum optimal, sedangkan rendahnya perlakuan lama fermentasi 15 hari dan 20 hari disebabkan karena semakin lama waktu fermentasi akan menyebabkan kapang kekurangan nutrien sehingga aktifitas kapang menurun dan kapang menuju fase kematian.

\section{b. Kecernaan Nutrien \\ b. 1. Kecernaan Bahan Kering (KcBK)}

Rataan kecernaan BK pelepah sawit yang difermentasi kapang Phanerochaete chrysosporium pada masing-masing perlakuan dilihat pada Tabel 2. Hasil sidik ragam menunjukkan pengaruh cenderung berinteraksi yang diuji pada taraf $10 \%$ $(\mathrm{P}<0,01)$ antara pemberian dosis mineral $(\mathrm{A})$ dengan lama fermentasi $(\mathrm{Y})$.

Peningkatan KcBK pada perlakuan A3Y1 (pemberian dosis $2.000 \mathrm{ppm}$ dengan lama fermentasi 10 hari) disebabkan karena meningkatnya kandungan bahan kering substrat setelah fermentasi. Meningkatnya kandungan bahan kering setelah fermentasi ini disebabkan karena proses degradasi lignin oleh kapang Phanerochaete chrysosporium pada perlakuan A3Y1 (pemberian dosis 2.000 ppm dengan lama waktu 10 hari) terjadi secara optimal. Perombakan lignoselulosa pada pelepah sawit akan meningkatkan ketersediaan nutrient yang mendukung perkembangan miselia kapang. Suparjo dan Nelson (2012) menyatakan kecernaan bahan kering buah kakao (KBK) dengan dosis mineral Ca 1190 ppm dengan lama fermentasi 10 hari menghasilkan kecernaan yang lebih baik yaitu sebesar $59,61 \%$ perbedaan ini disebabkan karena substrat yang digunakan berbeda. Suparjo et al. (2009) menyatakan perbanyakan jumlah miselia kapang sebagai indikator pertumbuhan selama proses dapat meningkatkan kandungan bahan kering.

Rendahnya KcBK pada perlakuan A1 (1.000 ppm) dan A2 (1.500 ppm) disebabkan karena pemberian mineral dengan dosis 1000 ppm dan 1.500 ppm belum dapat mengoptimalkan kerja enzim yang dihasilkan oleh kapang dalam mendegradasi lignin. Lama fermentasi Y2 (15 hari) dan Y3 (20 hari) menunjukan penurunan kecernaan jika 
Tabel 3. Rataan kecernaan bahan organik (KcBO) dalam \%.

\begin{tabular}{|c|c|c|c|c|c|}
\hline \multirow{2}{*}{ Waktu (Y) } & \multicolumn{4}{|c|}{ Dosis } & \multirow[b]{2}{*}{ Rataan } \\
\hline & A0 & A1 & A2 & A3 & \\
\hline Y1 & 43,52 & 46,34 & 50,27 & 53,24 & $48,34^{\mathrm{a}}$ \\
\hline Y2 & 42,17 & 44,37 & 49,39 & 51,22 & $46,79^{\mathrm{b}}$ \\
\hline Y3 & 41,02 & 43,20 & 47,11 & 50,43 & $45,44^{\mathrm{c}}$ \\
\hline Rataan & $42,24^{\mathrm{d}}$ & $44,64^{c}$ & $48,92^{\mathrm{b}}$ & $51,63^{\mathrm{a}}$ & 46,86 \\
\hline
\end{tabular}

Keterangan: Superskrip yang berbeda pada baris dan kolom yang sama menunjukkan berbeda sangat nyata $(\mathrm{P}<0,01)$

dibandingkan dengan A1 (10 hari) dimana waktu 10 hari merupakan fase stasioner kapang sehingga aktifitas enzim yang dihasilkan oleh kapang dalam mendegradasi lignin bekerja secara maksimal, sedangkan semakin lama waktu fermentasi dalam hal ini adalah Y2 (15 hari) dan Y3 (20 hari) menyebabkan ketersediaan nutrient yang dibutuhkan oleh kapang semakin lama semakin habis dan menyebabkan kapang menuju fase kematian. Rendahnya KcBK pada perlakuan disebabkan belum optimalnya aktifitas kapang yang tidak dipicu oleh pemberian mineral terhadap substrat fermentasi. Hal ini dibuktikan dengan rendahnya kandungan BK substrat A0 setelah fermentasi dibandingkan dengan perlakuan lainnya.

\section{b. 2. Kecernaan Bahan Organik (KcBO)}

Rataan KcBO pelepah sawit yang difermentasi kapang Phanerochaete chrysosporium dapat dilihat pada Tabel 3.

Hasil sidik ragam $\mathrm{KcBO}$ menunjukan pengaruh tidak berbeda nyata $(P>0.05)$ antara pemberian dosis mineral (A) dengan lama fermentasi $(\mathrm{Y})$, akan tetapi pemberian dosis mineral (A) dan lama fermentasi (Y) memberikan pengaruh sangat nyata $(\mathrm{P}<0.01)$ terhadap peningkatan kecernaan BO pelepah difermentasi menggunakan kapang Phanerochaete chrysosporium.

Rendahnya KcBO pada perlakuan A0 jelas terlihat pada kandungan $\mathrm{BO}$ substrat setelah fermentasi lebih rendah dibandingkan dengan perlakuan lainnya. Rendahnya kecernaan BO ini disebabkan karena belum optimalnya pertumbuhan miselium kapang yang tidak dipicu oleh ketersediaan mineral dalam substrat sehingga enzim yang dihasilkan lebih sedikit dan membuat aktifitas enzim yang dihasilkan tidak dapat bekerja secara optimal sehingga kandungan lignoselulosa dan selulosa substrat masih tinggi sehingga sulit dicerna oleh mikroba rumen. Rendahnya $\mathrm{KcBO}$ pada perlakuan A1 (1.000 ppm) dan A2 (1.500 ppm) disebabkan karena pemberian mineral dengan dosis 1.000 ppm dan 1.500 ppm belum dapat mengoptimalkan kerja enzim yang dihasilkan oleh kapang dalam mendegradasi lignin. Lama fermentasi Y2 (15 hari) dan Y3 (20 hari) menunjukan penurunan kecernaan jika dibandingkan dengan A1 (10 hari) dimana waktu 10 hari merupakan fase stasioner kapang sehingga aktifitas enzim yang dihasilkan oleh kapang dalam mendegradasi lignin bekerja secara maksimal, sedangkan semakin lama waktu fermentasi dalam hal ini adalah Y2 (15 hari) dan Y3 (20 hari) menyebabkan ketersediaan nutrien yang dibutuhkan kapang semakin lama semakin habis dan menyebabkan kapang menuju fase kematian. Fardiaz (1989) menyatakan dengan bertambahnya waktu fermentasi maka ketersediaan nutrient dalam media habis sehingga kapang lama-kelamaan akan mati. Waktu fermentasi dalam memproduksi enzim yang berbeda akan menghasilkan aktivitas enzim yang berbeda (Suhartono, 1989). Maynard et al. (1979) menyatakan lignin merupakan faktor pembatas degradasi zat-zat makanan terutama bahan kering, bahan organik dan protein kasar dalam bahan makanan.

Tingginya nilai $\mathrm{KcBO}$ pada perlakuan $\mathrm{A} 3$ (2.000 ppm) dan perlakuan Y1 (10 hari) yaitu $53,24 \%$ seiring dengan peningkatan kandungan BO substrat setelah fermentasi, hal ini megindikasikan penambahan dosis mineral 
Tabel 4. Rataan kecernaan protein kasar (KcPK) dalam \%.

\begin{tabular}{|c|c|c|c|c|c|}
\hline \multirow{2}{*}{ Waktu (Y) } & \multicolumn{4}{|c|}{ Dosis } & \multirow{2}{*}{ Rataan } \\
\hline & A0 & A1 & A2 & A3 & \\
\hline Y1 & $41,00^{\mathrm{gh}}$ & $43,21^{\text {de }}$ & $44,84^{b c}$ & $47,54^{\mathrm{a}}$ & 44,15 \\
\hline Y2 & $40,46^{\mathrm{gh}}$ & $42,09^{\mathrm{ef}}$ & $43,60^{\mathrm{cd}}$ & $47,47^{\mathrm{a}}$ & 43,41 \\
\hline $\mathrm{Y} 3$ & $39,29^{\mathrm{h}}$ & $39,94^{\mathrm{fg}}$ & $43,13^{\text {cde }}$ & $44,33^{\mathrm{b}}$ & 41,67 \\
\hline Rataan & 40,25 & 41,75 & 43,86 & 46,45 & 43,08 \\
\hline
\end{tabular}

Keterangan: Superskrip yang berbeda pada baris dan kolom yang sama menunjukkan berbeda sangat nyata $(\mathrm{P}<0,01)$.

2.000 ppm dapat meningkatkan jumlah miselia kapang sehingga dapat meningkatkan nutrient substrat. Aktifitas kapang Phanerochaete chrysosporium dalam perombakan komponen lignoselulosa substrat dapat menyebabkan ketersediaan nutrien dalam substrat meningkat dan digunakan oleh kapang untuk memicu pertumbuhan dan peningkatan jumlah miselia kapang. Suparjo dan Nelson (2012) menyatakan kecernaan bahan kering dan bahan organik kulit buah kakao (KBK) dengan dosis mineral Ca 1.190 ppm dengan lama fermentasi 10 hari menghasilkan kecernaan yang lebih baik sebesar $59,61 \%$ dan $61,03 \%$, perbedaan ini pelepah sawit substrat yang digunakan berbeda.

Pengukuran kecernaan dengan in vitro dapat menggambarkan bagaimana hasil aktifitas dari kapang Phanerochaete chrysosporium dalam fermentasi pelepah sawit yang dilakukan pada penelitian ini, kecernaan ini juga dipengaruhi oleh aktifitas mikroba rumen dimana aktifitas mikroba rumen ini juga dipengaruhi oleh lama waktu inkubasi yaitu 48 jam, dimana semakin lama waktu inkubasi maka jumlah mikroba rumen juga akan menurun. Dalam waktu 20 jam mikroba dapat mengalami kematian karena zat makanan yang dibutuhkan untuk beraktifitas menjadi berkurang atau habis (Dwijo Saputro, 1994).

\section{b. 2. Kecernaan Protein Kasar (KcPK)}

Rataan kecernaan PK pelepah sawit yang difermentasi kapang Phanerochaete chrysosporium dapat dilihat pada Tabel 4.

Hasil sidik ragam terhadap KcPK menunjukkan pengaruh cenderung berinteraksi yang diuji pada taraf $10 \%$
$(\mathrm{P}<0,10)$ antara pemberian dosis mineral $(\mathrm{A})$ dengan lama fermentasi (Y). Hasil uji lanjut DMRT terhadap interaksi masing-masing perlakuan terhadap KcPK menunjukkan perlakuan A3Y1 (pemberian dosis mineral 2.000 ppm dengan lama fermentasi 10 hari) dan A3Y2 (pemberian dosis 2.000 ppm dengan lama fermentasi 15 hari) berbeda sangat nyata lebih tinggi $(\mathrm{P}<0,01)$ terhadap peningkatan KcPK jika dibandingkan dengan perlakuan lainnya.

Tingginya KcPK pada perlakuan A3Y1 (pemberian dosis $2.000 \mathrm{ppm}$ dengan lama fermentasi 10 hari) dan A3Y2 (pemberian dosis $2.000 \mathrm{ppm}$ dengan lama fermentasi 15 hari) disebabkan karena kandungan PK pada perlakuan A3Y1 (2.000 ppm dan 10 hari) dan A3Y2 (2.000 ppm dan 15 hari) tidak berbeda nyata. Kecernaan terendah diperoleh pada perlakuan A0 (0 ppm) dan Y3 (20 hari) sebesar $39.29 \%$. Perbedaan KcPK yang signifikan ini sama halnya pada KcBK dan $\mathrm{KcBO}$ hal ini karena PK merupakan bagian dari BO dan BO merupakan bagian dari BK. Meningkatnya KcPK dipengaruhi oleh meningkatnya kandungan PK substrat fermentasi. Peningkatan kandungan PK disebabkan karena peningkatan jumlah massa sel kapang. Sekresi enzim ekstraseluler oleh kapang Phanerochaete chrysosporium juga berperan dalam meningkatkan kandungan protein biomassa substrat fermentasi (Nelson dan Suparjo, 2011). Imsya (2013) menyatakan meningkatnya kandungan protein kasar daun sawit fermentasi disebabkan terjadinya perombakan bahan organik, perombakan bahan organik ini menyebabkan perubahan persentase kandungan nutrient substrat.

Rendahnya KcPK pada penambahan dosis 1.000 ppm, dan 1.500 ppm disebabkan karena 
Tabel 5. Rataan kecernaan NDF (\%).

\begin{tabular}{|c|c|c|c|c|c|}
\hline \multirow{2}{*}{ Waktu (Y) } & \multicolumn{4}{|c|}{ Dosis } & \multirow{2}{*}{ Rataan } \\
\hline & A0 & A1 & $\mathrm{A} 2$ & A3 & \\
\hline Y1 & 39,47 & 41,64 & 43,91 & 47,48 & $43,12^{a}$ \\
\hline Y2 & 37,37 & 40,33 & 43,43 & 46,21 & $41,84^{b}$ \\
\hline Y3 & 35,98 & 38,69 & 42,63 & 45,01 & $40,58^{c}$ \\
\hline Rataan & $37,61^{\mathrm{d}}$ & $40,22^{\mathrm{c}}$ & $43,32^{\mathrm{b}}$ & $46,23^{a}$ & 41,85 \\
\hline
\end{tabular}

Keterangan: Superskrip yang berbeda pada baris dan kolom yang sama menunjukkan berbeda sangat nyata $(\mathrm{P}<0,01)$.

penambahan dosis $1.000 \mathrm{ppm}$ dan $1.500 \mathrm{ppm}$ belum dapat mengoptimalkan pertumbuhan miselia kapang sehingga enzim yang dihasilkan sedikit dan menyebabkan proses degradasi lignin tidak dapat terjadi dengan baik. Hal ini dibuktikan dengan kandungan PK substrat setelah fermentasi lebih rendah jika dibandingkan dengan perlakuan A3Y1 (pemberian dosis 2.000 ppm dengan lama fermentasi 10 hari). Rendahnya KcPK pada perlakuan Y2 (15 hari) dan Y3 (20 hari) jika dibandingkan dengan waktu Y1 (10 hari) disebabkan karena waktu 10 hari merupakan waktu dimana kapang dalam fase stasioner, semakin lama waktu fermentasi akan membuat nutrien yang ada dalam substrat yang dibutuhkan oleh kapang akan habis sehingga lama kelamaan kapang menuju fase kematian.

Nelson dan Suparjo (2011) menyatakan peningkatan kandungan protein ini disebabkan karena biokonversi gula menjadi protein miselium atau protein sel tunggal. Semakin banyak miselium akibat pertumbuhan jamur makin banyak nitrogen tubuh dan ini merupakan sumbangan protein bagi substrat yang difermentasi (Musnandar, 2003). Ditambahkan (Jonathan et al., 2008) peningkatan kandungan protein kasar pada proses fermentasi kemungkinan disebabkan hasil dari penambahan dari biomassa kapang terhadap substrat fermentasi. Dinding sel jamur mengandung $6,3 \%$ protein, sedangkan membran sel pada jamur yang berhifa mengandung protein $25-45 \%$, dan karbohidrat 25-30\% (Garraway dan Evans, 1984).

Peningkatan KcPK ini ditandai dengan kandungan protein substrat yang meningkat sehingga ketersediaan $\mathrm{N}$ lebih banyak yang dapat dimanfaat oleh mikroba rumen untuk meningkatkan sintesis protein mikroba. Peningkatan efisiensi sintesis protein mikroba diantaranya dapat dicapai dengan sinkronisasi laju degradasi protein dan karbohidrat yang sama-sama lambat atau yang sama-sama cepat (Karsli dan Russel, 2001).

\section{c. Kecernaan Fraksi Serat c. 1. Kecernaan NDF}

Rataan kecernaan NDF pelepah sawit yang difermentasi kapang Phanerochaete chrysosporium dapat dilihat pada Tabel 5.

Hasil sidik ragam terhadap kecernaan NDF menunjukkan pengaruh tidak berbeda nyata $(\mathrm{P}>0,05)$ antara pemberian dosis mineral (A) dengan lama fermentasi (Y), tetapi masing-masing faktor yaitu pemberian dosis mineral (A) dan lama fermentasi (Y) memberikan pengaruh sangat nyata $(\mathrm{P}<0,01)$ terhadap peningkatan kecernaan NDF daun sawit yang difermentasi menggunakan kapang Phanerochaete chrysosporium.

Tingginya kecernaan NDF pada perlakuan A3 (pemberian dosis $2.000 \mathrm{ppm}$ ) dan $\mathrm{Y} 1$ (lama fermentasi 10 hari) dibandingkan dengan perlakuan lainnya disebabkan karena kandungan lignin serta fraksi serat NDF produk fermentasi lebih rendah. Tingginya kecernaan NDF pada perlakuan A3 (2.000 ppm) dan Y1 (10 hari) ini disebabkan karena pada perlakuan ini telah terjadi proses degradasi lignin secara optimal yang ditandai dengan penurunan kandungan lignin terbesar yaitu 26,79\%. Hal ini mengindikasikan pemberian dosis hingga $2.000 \mathrm{ppm}$ yang didukung dengan lama fermentasi 10 hari dimana merupakan fase stasioner kapang dapat meningkatkan pertumbuhan miselia kapang sehingga enzim yang dihasilkan lebih banyak dan membuat aktifitas enzim dalam 
Tabel 6. Rataan kecernaan ADF (\%).

\begin{tabular}{|c|c|c|c|c|c|}
\hline \multirow{2}{*}{ Waktu (Y) } & \multicolumn{4}{|c|}{ Dosis } & \multirow{2}{*}{ Rataan } \\
\hline & A0 & A1 & A2 & A3 & \\
\hline Y1 & $34,90^{\mathrm{de}}$ & $37,26^{\mathrm{c}}$ & $38,79^{b}$ & $42,24^{\mathrm{a}}$ & 38,30 \\
\hline Y2 & $33,73^{\mathrm{e}}$ & $34,81^{\mathrm{d}}$ & $37,62^{\mathrm{c}}$ & $41,21^{\mathrm{a}}$ & 36,84 \\
\hline Y3 & $30,91^{\mathrm{f}}$ & $34,12^{\mathrm{de}}$ & $36,71^{\mathrm{c}}$ & $39,75^{\mathrm{b}}$ & 35,37 \\
\hline Rataan & 33,18 & 35,40 & 37,71 & 41,07 & 36,84 \\
\hline
\end{tabular}

Keterangan: Superskrip yang berbeda pada baris dan kolom yang sama menunjukkan berbeda sangat nyata $(\mathrm{P}<0,01)$.

mendegradasi lignin dapat bekerja dengan optimal. Rendahnya kecernaan NDF pada perlakuan A0 (0 ppm), A1 (1.000 ppm), A2 $(1.500 \mathrm{ppm})$ disebabkan karena belum optimalnya pertumbuhan miselium kapang yang diharapkan dapat mensekresikan enzim yang lebih banyak untuk mendegradasi lignin substrat sehingga proses degradasi lignin belum optimal. Hal ini dibuktikan dengan masih tingginya kandungan NDF setelah fermentasi jika dibandingkan dengan perlakuan A3 (2.000 ppm) dan Y1 (10 hari). Rendahnya kecernaan NDF pada perlakuan Y2 (15 hari) dan Y3 (20 hari) disebabkan karena semakin lama waktu fermentasi membuat aktifitas kapang menurun karena ketersediaan nutrien dalam substrat semakin habis sehingga kapang menuju kematian. Wardani (2013) menyatakan pelepah sawit yang difermentasi dengan kapang Phanerochaete chrysosporium pada dosis inokulum $10^{7} \mathrm{cfu} / \mathrm{ml}$ pada lama fermentasi 10 hari dapat menurunkan kandungan NDF sebesar $42,49 \%$.

\section{c. 2. Kecernaan ADF}

Rataan kecernaan ADF pelepah sawit yang difermentasi kapang Phanerochaete chrysosporium dapat dilihat pada Tabel 6. Hasil sidik ragam terhadap kecernaan ADF menunjukkan pengaruh cenderung berinteraksi yang diuji pada taraf $10 \% \mathrm{P}<0,10)$ antara pemberian dosis mineral (A) dengan lama fermentasi (Y).

Tingginya kecernaan ADF pada perlakuan A3Y1 (pemberian dosis 2.000 ppm dengan lama fermentasi 10 hari) disebabkan karena penurunan kandungan lignin serta kandungan fraksi serat lainnya. Tingginya kecernaan pada perlakuan A3Y1 (pemberian dosis 2.000 ppm dengan lama fermentasi 10 hari) ini disebabkan karena pada perlakuan A3Y1 (pemberian dosis $2.000 \mathrm{ppm}$ dengan lama fermentasi 10 hari) telah terjadi proses degradasi lignin secara maksimal yang ditandai dengan penurunan kandungan lignin terbesar yaitu 26,79\%. Proses degradasi lignin yang bekerja dengan optimal ini mengindikasikan peningkatan dosis mineral Ca hingga $2.000 \mathrm{ppm}$ dapat meningkatkan jumlah miselium kapang dan menghasilkan enzim lebih banyak sehingga proses degradasi lignin pada daun sawit terjadi dengan sempurna.

Rendahnya kecernaan pada perlakuan A0, A1, A2, Y2 dan Y3 terlihat dari masih tingginya kandungan ADF substrat fermentasi dibandingkan dengan perlakuan A3 dan Y1. Hal ini disebabkan karena belum optimalnya pertumbuhan miselium kapang sehingga enzim yang dihasilkan sedikit, enzim yang sedikit ini belum mampu bekerja dengan optimal dalam proses mendegradasi lignin substrat sehingga kandungan lignin dan fraksi serat masih tinggi. Kandungan lignin dan fraksi serat yang masih tinggi ini membuat mikroba rumen sulit untuk mendegradasi pakan sehingga kecernaannya masih rendah.

Nilai kecernaan NDF dan ADF daun sawit yang difermentasi dengan menggunakan kapang Phanerochaete chrysosporium pada penelitian ini lebih tinggi dibandingkan hasil yang diperoleh Pulungan (2014) kecernaan NDF dan ADF batang kelapa sawit yang difermentasi dengan menggunakan kapang Phanerochaete chrysosporium dengan pemberian urea $0,3 \mathrm{~g}$ dengan lama fermentasi 13 hari yaitu $36,54 \%$ dan $36,50 \%$. 
Tabel 7. Rataan kecernaan selulosa (\%).

\begin{tabular}{cccccc}
\hline \multirow{2}{*}{ Waktu $(\mathrm{Y})$} & \multicolumn{3}{c}{ Dosis } & \multirow{2}{*}{ Rataan } \\
\cline { 2 - 5 } & $\mathrm{A} 0$ & $\mathrm{~A} 1$ & $\mathrm{~A} 2$ & $\mathrm{~A} 3$ & \\
\hline Y1 & 37,96 & 40,02 & 42,34 & 45,44 & $41,44^{\mathrm{a}}$ \\
Y2 & 37,45 & 39,08 & 41,48 & 44,07 & $40,52^{\mathrm{ab}}$ \\
Y3 & 36,69 & 38,29 & 40,65 & 42,88 & $39,63^{\mathrm{b}}$ \\
\hline Rataan & $37,37^{\mathrm{d}}$ & $39,13^{\mathrm{c}}$ & $41,49^{\mathrm{b}}$ & $44,13^{\mathrm{a}}$ & 40,53 \\
\hline
\end{tabular}

Keterangan: Superskrip yang berbeda pada baris dan kolom yang sama menunjukkan berbeda sangat nyata $(\mathrm{P}<0,01)$.

Tabel 8. Rataan kecernaan hemiselulosa (\%).

\begin{tabular}{cccccc}
\hline \multirow{2}{*}{ Waktu (Y) } & \multicolumn{3}{c}{ Dosis } & \multirow{2}{*}{ Rataan } \\
\cline { 2 - 5 } & A0 & A1 & A2 & A3 & \\
\hline Y1 & 39,68 & 42,60 & 45,31 & 48,34 & $43,98^{\mathrm{a}}$ \\
Y2 & 39,34 & 41,40 & 44,26 & 47,01 & $43,00^{\mathrm{ab}}$ \\
Y3 & 38,23 & 40,53 & 43,26 & 46,11 & $42,03^{\mathrm{b}}$ \\
\hline Rataan & $39,08^{\mathrm{d}}$ & $41,51^{\mathrm{c}}$ & $44,28^{\mathrm{b}}$ & $47,15^{\mathrm{a}}$ & 43,01 \\
\hline
\end{tabular}

Keterangan: Superskrip yang berbeda pada baris dan kolom yang sama menunjukkan berbeda sangat nyata $(\mathrm{P}<0,01)$.

\section{c. 3. Kecernaan Selulosa dan Hemiselulosa}

Rataan kecernaan selulosa dan hemiselulosa pelepah sawit yang difermentasi kapang Phanerochaete chrysosporium dapat dilihat pada Tabel 7 dan 8 .

Hasil sidik ragam menunjukkan masing-masing kecernaan selulosa dan hemiselulosa tidak terdapat interaksi $(\mathrm{P}>0,05)$ antara pemberian dosis mineral (A) dengan lama fermentasi (Y), akan tetapi masingmasing faktor yaitu pemberian dosis mineral (A) dan lama fermentasi (Y) memberikan pengaruh sangat nyata $(\mathrm{P}<0,01)$ terhadap peningkatan kecernaan selulosa dan hemiselulosa daun sawit yang difermentasi menggunakan kapang Phanerochaete chrysosporium.

Peningkatan kecernaan selulosa dan hemiselulosa pada pelepah sawit yang difermentasi menggunakan kapang Phanerochaete chrysosporium pada perlakuan A3 (2.000 ppm) dan Y1 (10 hari) ditandai dengan penurunan kandungan lignin dan beberapa komponen serat lainnya. Hal ini disebabkan karena pada perlakuan A3 dan Y1 telah terjadi proses degradasi lignin secara maksimal. Proses degradasi lignin yang bekerja dengan maksimal mengindikasikan peningkatan dosis mineral Ca hingga 2.000 ppm dapat meningkatkan jumlah miselium kapang dan menghasilkan enzim lebih banyak sehingga proses degradasi lignin pada pelepah sawit terjadi dengan sempurna dan dapat memutus ikatan lignoselulosa dan lignohemiselulosa sehingga mikroba rumen dapat memanfaatkan selulosa dan hemiselulosa untuk dirubah menjadi VFA. Selain itu kecernaan makanan tergantung pada aktifitas mikroba rumen karena mikroba rumen berperan dalam proses fermentasi, sedangkan aktifitas mikroba itu sendiri dipengaruhi oleh zat-zat makanan yang terdapat dalam bahan pakan (Crampton dan Harris, 1969).

Rendahnya kecernaan pada perlakuan A0 (0 ppm), A1 (1.000 ppm), A2 (1.500 ppm) pelepah sawit karena belum optimalnya kerja enzim yang dihasilkan oleh kapang dalam mendegradasi lignin, hal ini menyebabkan ikatan lignoselulosa dan lignohemiselulosa masih kuat sehingga mikroba rumen sulit untuk mendegradasi pakan. Rendahnya kecernaan Hemiselulosa dan Selulosa pada perlakuan Y2 (15 hari) dan Y3 (20 hari) disebabkan karena semakin lama waktu fermentasi menyebabkan nutrien substrat yang dibutuhkan oleh kapang akan habis sehingga kapang menuju fase kematian. Hal ini dapat dibuktikan dengan masih tingginya kandungan fraksi serat hemiselulosa dan selulosa setelah 
fermentasi jika dibandingkan perlakuan A3 (2.000 ppm) dan Y1 (10 hari).

Tuomela et al. (2000) menyebutkan Phanerochaete chrysosporium merupakan kapang pelapuk putih yang mampu mendegradasi komponen lignoselulosa secara selektif dengan merombak lignin terlebih dahulu kemudian diikuti dengan selulosa (Suparjo, 2010). Potensi jamur pelapuk putih untuk mendegradasi lignin tergantung pada strain, jenis fermentasi serta lama inkubasi (Dinis et al., 2009).

\section{KESIMPULAN}

Fermentasi pelepah sawit menggunakan kapang Phanerochaete chrysosporium pada dosis mineral $\mathrm{Ca} 2.000$ ppm dengan lama fermentasi 10 hari dapat menurunkan kandungan lignin sebesar 26,79\% dengan tingkat kecernaan BK 51,44\%., BO 53,24\%., PK 47,54\%., NDF 47,48\%., ADF 42,24\%., selulosa $45,44 \%$ dan hemiselulosa $48,34 \%$, sehingga hasil fermentasi ini dapat digunakan sebagai bahan penyusun ransum ternak.

\section{DAFTAR PUSTAKA}

Alimon, A.R. and M. Hair-Bejo. 1996. Feeding system based on oil palm byproduct in Malaysia. Proc. of the First International Symposium on the Integration of Livestock to Oil Palm Production. Kuala Lumpur, Malaysia 25 - 27 May 1995.

Crampton, E.W and L.E. Harris. 1969. Applied Animal Nutrition. $2^{\text {nd }}$ Ed. W.H. Freeman and Co.San Fransisco.

Dinis, M.J., R.M.F. Bezerra., F. Nunes, A.A. Dias, C.V. Guedes, L.M.M. Ferreira., J.W. Cone, G.S.M. Marques, A.R.N. Barros, M.A.M. Rodrigues. 2009. Modification of wheat straw lignin by solid state fermentation with white-rot fungi. Bioresource Tech. 100:48294835. oi:10.1016/j.biortech.2009.04.036.
Direktorat Jenderal Perkebunan. 2012. Statistik Perkebunan. Direktorat Jenderal Perkebunan, Jakarta.

Ditjen PPHP. 2006. Pedoman pengelolaan limbah industri kelapa sawit. Jakarta.

Fadilah dan S. Distantina.2009. Delignifikasi ampas batang aren: pembandingan pengaruh penambahan glukosa dengan penambahan tetes. Ekuilibrium. Vol 18(2):19-25.

Fardiaz, S. 1989. Fisiologi Fermentasi. PAU Pangan Gizi. IPB. Bogor.

Garraway, M.D. and R.C. Evans. 1984. Fungal Nutrition \& Physiology. John Wiley \& Sons, Singapore.

Gupte, A., S. Gupte and H. Patek. 2007. Ligninolytic enzyme production under solid-state fermentation by white rot fungi. J. Scient Industr. Res. 66:622614.

Imsya, A. 2013. Hasil biodegradasi lignoselulosa pelepah kelapa sawit (Elaeis guineensis) oleh Phanerochaete chrysosporium sebagai antioksidan dan bahan pakan ternak ruminansia. Disertasi. Sekolah Pascasarjana IPB. Bogor.

Ishida, M. and O.B. Hassan. 1992. Utilization of oil palm fround as cattle feed. JARQ. 31(1): $41-47$.

Jonathan SG., I.O. Fasidi., A.O. Ajayi., A. Adegeye. 2008. Biodegradation of Nigerian wood waste by Pleurotus tuber-regium (Fries) Singer. Bioresource and Technology 99: 807811.

Karsli M.A, and J.R Russell. 2001. Effects of some dietary factor on ruminal microbial protein synthesis. Turk J Vet. Anim Sci. 25 : 681-686.

Leisola, M. S., S. Garcia. 1989. The Mechanisme of Lignin Degradation. Finnish Sugar Co. Ltd. Research Centre. Kantvik. Finland. 
Maynard, L. A., J. K. Loosly., H. Flints and R. G. Werner. 1979. Animal Nutrition. $6^{\text {th }}$ Ed. Longman Group. Ltd. London and New York.

Musnandar, E. 2003. Pengaruh dosis inokulum marasmius sp. dan lama inkubasi terhadap kandungan komponen serat dan protein murni pada sabut kelapa sawit untuk bahan pakan ternak. Jurnal Ilmiah Ilmu-Ilmu Peternakan Nopember, 2006, Vol. IX. No.4.

Nelson dan Suparjo. 2011. Penentuan lama fermnetasi kulit buah kakao dengan Phanerochaete chrysosporium evaluasi kualitas nutrisi secara kimiawi. Agrinak.Vol.01(1):1-10. ISSN: 20888643.

Nelson. 2011. Degradasi bahan kering dan produksi asam lemak terbang in vitro pada kulit buah kakao fermentasi. Jurnal Ilmiah Ilmu-Ilmu Peternakan. Vol.XIV.No1.

Sirait, J., N.D. Purwantari dan K. Simanihuruk. 2005. Produksi dan serapan nitrogen rumput pada naungan dan pemupukan yang berbeda.

Steel, R. G. D and J. H. Torrie. 1991. Prinsip dan Prosedur Statistika. Suatu Pendekatan Biometrik. Terjemahan. Edisi Kelima. PT. Gramedia Pustaka Utama, Jakarta.

Suhartono. 1989. Enzim dan Bioteknologi. IPB. Bogor.

Suparjo dan Nelson. 2012. Fraksi serat dan kecernaan invitro kulit buah kakao yang difermentasi dengan Phanerochaete chrysosporium. Agrinak Vol.02(01):4148.
Suparjo. 2010. Peningkatan kualitas nutrisi kulit buah kakao sebagai pakan ternak secara bioproses dengan Phanerochaete chrysosporium yang diperkaya ion $\mathrm{Mn}^{2+}$ dan $\mathrm{Ca}^{2+}$. Disertasi Sekolah Pascasarjana Institut Pertanian Bogor. Bogor.

Suparjo., K. G. Wiryawan., E. B. Laconi dan D. Mangunwidjaja. 2009. Perubahan komposisi kimia kulit buah kakao akibat penambahan mangan dan kalsium dalam biokonversi dengan kapang Phanerochaete chrysosporium. Media Peternakan. Vol. 32 No. 3. hlm. 204-211.

Suparjo., K. G. Wiryawan., E. B. Laconi dan D. Mangunwidjaja. 2009. Perubahan komposisi kimia kulit buah kakao akibat penambahan mangan dan kalsium dalam biokonversi dengan kapang Phanerochaete chrysosporium. Media Peternakan. Vol. 32 No. 3. hlm. 204-211.

Takano M., M. Nakamura, A. Nishida, and M. Ishihara. 2004. Manganase peroxidase from Phanerochaete crassa WD1694. Bull.

Wuyep,P.A., A.U. Khan., A.J. Nok. 2003. Production and regulation of lignin degrading enzymes from Lentinus squarrosulus (Mont) singer and Psathyrellaatroumbonata Pegler. African J Biotechnol. 2(11):444-447.

Zacchi, L., I. Morris, \& P. J. Harvey. 2000. Disorder ultrastructure in lignin peroxidase secreting hyphae of the white-rot fungus Phanerochaete chrysosporium. 